Part of Journal of Research of the National Bureau of Standards, Volume 23, December 1939

\title{
POTENTIOMETRIC METHOD FOR THE ACCURATE MEASUREMENT OF HYDROGEN-ION ACTIVITY
}

\author{
By Walter J. Hamer and S. F. Acree
}

\section{ABSTRACT}

A potentiometric method is described for measurements of hydrogen-ion activities in aqueous solutions.

Galvanic cells without liquid junctions are used. In this method hydrogen and silver-silver chloride electrodes are placed in solutions to which known amounts of either sodium or potassium chloride have been added. A detailed description is given of the equipment and experimental procedures which are necessary for precise measurements of hydrogen-ion activities. The electromotive force of the galvanic cell, on the average, is reproducible to $0.02 \mathrm{mv}$ which is equivalent to $0.0003 \mathrm{pH}$ unit. It is found that the electrodes function reversibly and exhibit no aging, hysteresis, or polarization effects.

W It is shown how the hydrogen-ion activity may be calculated from the electromotive force by thermodynamic methods, using the Nernst equation, in which the concepts of activity and interionic attraction are incorporated.

\section{CONTENTS}

I. Introduction

II. Discussion of method

III. Description of equipment and experimental procedures_....... 651

1. Assembly of equipment

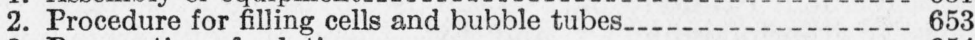

3. Preparation of solutions

4. Hydrogen electrodes and purification of hydrogen gas.

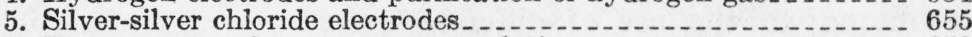

6 . Thermostat and temperature regulation $\ldots$

7. Instruments for measuring electromotive force

IV. Data illustrating precision of measurements

V. References_..._.

\section{INTRODUCTION}

The importance of the measurement and control of hydrogen-ion activities in industrial, biological, and scientific work is now firmly established. The two principal means for determining hydrogen-ion activities are the potentiometric and colorimetric methods. ${ }^{1}$ The

1 The conductometric and catalytic methods are supplementary. The conductance of a solution depends upon the concentration and mobility of all the ions in the solution. Therefore, it is necessary to have some detailed knowledge of the constituents of a solution and of the properties of each before any information on the hydrogen- or hydroxyl-ion activity can be obtained by the conductivity method. Likewise, in the catalytic method, it is necessary to know whether the hydrogen or hydroxyl-ion catalyzes a reaction, and if so, the relationship between the activity of the hydrogen or hydroxyl-ion and the rate of the reaction. These facts must be determined for every case and the method, therefore, is not a general or a fundamental one. In the case of other physical methods, such as the use of refractive indices of a solution, the relationship between the hydrogen- or hydroxyl-ion activity and the physical quantity measured must also be determined for each special case. 
former is the basic method. In the colorimetric method, the color changes of an indicator must be correlated with a definite change in hydrogen-ion activity, and the latter change must be determined by potentiometric methods.

The potentiometric methods depend upon the use of various types of electrodes. Of these, the hydrogen electrode has been arbitrarily chosen as the standard and the potentials of all other electrodes are referred to its potential. It is assumed to give a correct measurement of hydrogen-ion activity, and has been chosen for accurate determinations of $\mathrm{pH}$, which has been defined as the negative of the common logarithm of the hydrogen-ion activity ${ }^{2}$ and is so used in this paper.

The galvanic cell which has been used for accurate determinations of $\mathrm{pH}$ and for standardization of the $\mathrm{pH}$ scale $[1,3,4,5,6,14]^{3}$ consists of a hydrogen electrode, a buffer solution, and a calomel half-cell. This type of cell is one with a liquid junction formed by the contact of the $\mathrm{KCl}$ solution of the calomel half-cell and the buffer solution.

Although extensive investigations have been made and numerous papers have been written on the applications of this type of galvanic cell to the determinations of $\mathrm{pH}$, considerable diversity still persists in the results obtained. For example, the $\mathrm{pH}$ of 0.05 molar potassium acid phthalate, most commonly employed as a standard solution having a definite $\mathrm{pH}$ value, has been reported to be 3.94 [2], 3.974 [3], 4.005 [4], 4.008 [5], and 4.010 [6] at $25^{\circ} \mathrm{C}$, the maximum difference corresponding to $0.0042 v$ in the emf of the galvanic cell. The $\mathrm{pH}$ values reported for other solutions show similar differences. Although for many industrial processes the differences in $\mathrm{pH}$ values reported for potassium acid phthalate are well within the $\mathrm{pH}$ tolerance, these variations introduce misconceptions as to the accuracy and reproducibility obtainable with an individual $\mathrm{pH}$ assembly and are significant for many types of work. Furthermore, these differences indicate the lack of an establishment of a definite reference point on the $\mathrm{pH}$ scale or a lack of an accurate standardization of this scale. This lack of agreement is due in part to the use, by some workers, of the exact laws of thermodynamics and by others of nonthermodynamic or empirical methods of calculation; to differences in experimental technique; to the use of different values for the potential of the calomel half-cell; and to the use of different definitions for $\mathrm{pH}$ (footnote 2). The lack of agreement is due in larger part to use of galvanic cells with liquid junctions, which introduce into the total emf a potential whose magnitude depends upon the manner in which the junction is formed and can only be approximately calculated for any type of junction [7].

It is the purpose of this paper to describe an accurate potentiometric method for determinations of $\mathrm{pH}$ in which galvanic cells without liquid junctions are employed and to describe equipment and experimental

${ }^{2} \mathrm{pH}$ has also been defined (1) as the negative of the common logarithm of the hydrogen-ion concentration, (2) as some value between the negative of the common logarithms of the hydrogen-ion concentration and activity, and (3) as a quantity proportional to the emf of a galvanic cell with liquid junction and termed "pH number" without regard to physical interpretation. It is generally believed that the hydrogen-ion activity is the important quantity in industrial, biological, and chemical reactions, and is, therefore, employed in this paper as the basis for the definition of $\mathrm{pH}$. These other definitions have been proposed because a differentiation between activity and concentration cannot be clearly made on a thermodynamic basis. It is, however, not a question of making this differentiation but of the degree in which it can be made, S $\phi r e n s e n$ and Linderstr $\phi m$-Lang, Compt. rend. trav. lab. Carlsberg, 15, 40 (1924) suggested using $p_{\mathrm{H}}$ for the negative of the common logarithm of the hydrogen-ion activity. Although introduction of this symbol has some justifications, its use is confusing, and it appears more logical to redefine the symbol $\mathrm{pH}$ than to propose new symbols.

3 Figures in brackets indicate the literature references at the end of this paper. 
technique by which measurements may be made with high precision at temperatures from $0^{\circ}$ to $60^{\circ} \mathrm{C}$. In principle, the method is similar to the one employed in recent years by Harned and associates [8] in determinations of the thermodynamic ionization constants of weak electrolytes. Although galvanic cells without liquid junctions have been used for various purposes, they have not been used for determinations of $\mathrm{pH}$ values, ${ }^{4}$ or for a standardization of the $\mathrm{pH}$ scale. Measurements are made at the different temperatures in order to obtain information about the variation of hydrogen-ion activity values with temperature.

\section{DISCUSSION OF METHOD}

A silver-silver chloride and a hydrogen electrode are placed in an aqueous solution, and a known amount of either sodium or potassium chloride is added to the solution. It is necessary to add the chloride so that the silver-silver chloride electrode will function reversibly and give a reproducible potential. The silver-silver chloride electrode is chosen as the reference electrode, because it is only slightly soluble in most dilute solutions, is attacked by few materials, exhibits very little temperature hysteresis, recovers quickly from accidental concentration polarization, and its potential relative to the "normal hydrogen electrode" is known for a wide temperature range with a precision of about 0.02 to $0.05 \mathrm{mv}$ [9].

This galvanic cell without liquid junction may be represented by

$$
\left.\mathrm{Pt}\left|\mathrm{H}_{2}(\mathrm{~g})\right| \text { solution }+\mathrm{NaCl} \text { (or } \mathrm{KCl}\right)|\mathrm{AgCl}(\mathrm{s})| \mathrm{Ag}(\mathrm{s}) \text {, }
$$

in which $\mathrm{g}=$ gas, $\mathrm{s}=$ solid, and the vertical lines indicate the junction of two phases, as in the convention adopted in the International Critical Tables [10]. The emf of this cell is proportional to the activities of the hydrogen and chloride ions and is represented for 1 atmosphere of hydrogen pressure by the equation

$$
E=E^{\circ}-\frac{R T}{F} \ln \left(\mathrm{H}^{+}\right)\left(\mathrm{Cl}^{-}\right),
$$

where $E$ represents the measured emf; $E^{\circ}$ the "normal" electrode potential of the silver-silver chloride electrode; $\left(\mathrm{H}^{+}\right)$the hydrogen-ion activity; $\left(\mathrm{Cl}^{-}\right)$the chloride-ion activity; and $R, T$, and $F$ have their usual significance. Rearranging and converting to common logarithms gives

$$
\frac{\left(E-E^{\circ}\right) F}{2.3026 R T}+\log \left(\mathrm{Cl}^{-}\right)=-\log \left(\mathrm{H}^{+}\right)=\mathrm{pH},
$$

by which the $\mathrm{pH}$ of the solution may be calculated, provided the activity of the chloride ion in solution is known. When the activity of the chloride ion is not known, it may be calculated by using the known concentrations of the solution, added chloride, and the theoretical equation of Debye and Hückel [11] in the form suggested by Hückel [12]. Hückel's equation is valid for a considerably wider range of concentration than is the original equation of Debye and Hückel. For example, Harned and Ehlers [9] have shown that the activity

\footnotetext{
1 Guggenheim, J. Phys. Chem. 34, 1758 (1930) and Hitchcock, J. Am. Chem. Soc. 58, 855 (1936) have suggested their use in determining a quantity proportional to the hydrogen-ion "concentration"; and Hamer, Trans. Electrochem. Soc. 72,45 (1937) showed how galvanic cells without liquid junctions may be used in routine measurements of hydrogen-ion "concentrations."
} 
coefficients of $\mathrm{HCl}$ may be represented successfully by the Hückel equation over the concentration range of 0 to 4 molal. The activity of an ion is a function of the concentration, and the ratio of the activity to the concentration is termed the activity coefficient, ${ }^{\mathrm{b}}$ represented by $f_{i}$.

Hence the activity of the chloride ion $\left(\mathrm{Cl}^{-}\right)$is equal to the product of the chloride-ion concentration $\left[\mathrm{Cl}^{-}\right]$and the activity coefficient of the chloride ion, $f_{\mathrm{Cl}}$. Hückel [12], from theoretical considerations of the electrostatic forces between positive and negative ions in concentrated solutions, found that the activity coefficient of an ion is given as a function of the concentration in moles per liter by the equation

$$
\log f_{i}=\frac{-A z_{i}{ }^{2} \sqrt{\mu}}{1+B a_{i} \sqrt{\mu}}+\beta \mu
$$

where $A$ and $B$ are general constants applying to all aqueous solutions; $a_{i}$ and $\beta$ are constants characteristic of the solution studied; $\mu$ is the ionic strength of the solution in moles per liter and defined as half the sum of the concentration of each ion multiplied by the square of its valence, and $z_{i}$ is the valence of the ion. In this method $z_{i}$ always has a value of one, since only the activity coefficient of $\mathrm{HCl}$, a uniunivalent electrolyte, is involved, as indicated in the emf equation. Substituting $\left[\mathrm{Cl}^{-}\right] f_{\mathrm{Cl}}$ for $\left(\mathrm{Cl}^{-}\right)$in eq 2 , and eq 3 for $f_{\mathrm{Cl}}$ gives

$$
\frac{\left(E-E^{\circ}\right) F}{2.3026 R T}+\log \left[\mathrm{Cl}^{-}\right]-\frac{A \sqrt{\mu}}{1+B a_{i \sqrt{\mu}}}+\beta \mu=-\log \left(\mathrm{H}^{+}\right)=\mathrm{pH} \text {. }
$$

It is now possible by means of this equation to calculate the $\mathrm{pH}$ of a solution from the measured emf, the ionic strength, and the known concentration of the sodium or potassium chloride added to the solution. ${ }^{6}$ Numerical values of $E^{\circ}, A$ and $B$ at temperatures from $0^{\circ}$ to $60^{\circ} \mathrm{C}$, inclusive, are given in a paper by Harned and Ehlers [9]. Values of $a_{i}$ and $\beta$ are known for a few electrolytes and electrolytic mixtures. If values of $a_{i}$ and $\beta$ are not known for the electrolyte or electrolytic mixture studied, it is well to employ solutions as dilute as is practical. For dilute solutions, the $B a_{i} \sqrt{\mu}$ and $\beta \sqrt{\mu}$ terms are of less

\footnotetext{
- The concentration of a solution may be expressed in one of three ways, namely, (1) moles of solute per liter of solution (volume concentration, $c$ ), (2) moles of solute per $1,000 \mathrm{~g}$ of solvent (molality, $m$ ), or (3) mole fraction $=N$. Corresponding to these units for the concentration of a solution there are three units for activity coefficients, represented, respectively, by $f, \gamma$, and $f$; the first two termed the practical activity coefficients and the last one termed the rational activity coefficient. For a relation between these, see MacInnes, The Principles of Electrochemistry, chap. 6, p. 131 (Reinhold Publishing Corp., New York, 1939). For illustration, only $c$ and $f$ will be employed in this paper. It should be pointed out that $c, m$, and $N$ will approach the same numerical value as the solution is made more dilute. For approximate results, these may be used interchangeably. For precise work and for standardization purposes, the units of concentration should be stated clearly.

${ }^{6}$ In this method it is assumed that sodium and potassium chloride in aqueous solutions are completely dissociated into ions. Ample justification of this assumption has been reported in the literature from results obtained from experiment and conclusions deduced from theory. See Falkenhagen, Electroly tes, translation by Bell, p. 51 (Claredon Press, Oxford, London, 1934), also MacInnes, The Principles of Electrochemistry, chap. 8. (Reinhold Publishing Corporation, New York, N. Y., 1939). It is also assumed that the activity coefficient of an individual ion can be determined. Actually, only the mean activity coefficient of the ions of a solute can be determined experimentally. It is necessary, therefore, to make some assumption in order to arrive at a value for the activity coefficient of an individual ion. See MacInnes, J. Am. Chem. Soc. 41, 1086 (1919); Scatchard, J.Am. Chem. Soc. 47, 696 (1925), and Guggenheim, J. Phys. Chem.34, 1758 (1930) for discussions of assumptions which may be used to calculate values of the activity coefficients of individual ions. Mean activity coefficients are employed to test the Debye-Hückel equation. Therefore, the constants, $\beta$ and $a_{i}$, are characteristic of a solute and not of individual ions. Hence, in using this equation to calculate the activity coefficient of an individual ion, it must be assumed that the activity coefficient of the ion is equal to the mean activity coefficient of a solute (in this case, HCl) composed in part of this ion. The hydrogen-ion activity may also be converted to hydrogen-ion concentration, using a similar assumption.
} 
significance in the calculations of values for $\log f_{\mathrm{Cl}}$ or $\mathrm{pH}$. Hence the method herein described is better adapted to solutions of a concentration of $0.1 M$ or less. For accurate work and for standardization purposes, it is necessary to know these values. They may be determined from studies of the thermodynamics of solutions, considerations of interactions of ions, or by other means, the details of which are beyond the scope of this paper.

It will be noted that the method herein described may also be used for routine determinations of the $\mathrm{pH}$ of aqueous solutions of unknown composition. The concentration of the sodium or potassium chloride added to the solution is employed in eq 2 instead of the activity of the chloride ion, in calculations of $\mathrm{pH}$. Unless the solution is extremely acid or contains large quantities of salts, the $\mathrm{pH}$ thus calculated will be the correct value within $\pm 0.1 \mathrm{pH}$ unit for most solutions.

\section{DESCRIPTION OF EQUIPMENT AND EXPERIMENTAL PROCEDURES}

For precise measurements of hydrogen-ion activity it is necessary (a) that the galvanic cells be maintained at constant temperature within $0.02^{\circ} \mathrm{C}$; (b) that the electrodes behave reversibly, or are not subject to appreciable polarization, overvoltage, or passivity; (c) that the electrodes exhibit no temperature hysteresis, do not change in potential with time and are not "poisoned"; and (d), that the solution studied be as free as possible from soluble impurities, particularly carbon dioxide, and undergo no reduction or catalytic change by the electrodes, heat, light, or other conditions to which they are exposed. When these conditions are attained, the galvanic cell is said to be in a state of equilibrium. For the hydrogen electrode, it is essential that the hydrogen gas and solutions contain no oxygen and be in gaseous and vapor equilibrium, and that a good surface for adsorption of hydrogen gas be used in its construction.

Descriptions of equipment and experimental procedures which have been used for precise measurements of the galvanic cell described above are given in the following sections.

\section{ASSEMBLY OF EQUIPMENT}

Figure 1 is a schematic diagram of the principal parts of the assembly of the cell designed for precise measurements without liquid junction. The cell and bubble tube are designed (1) so that they may be filled in the absence of air and will exclude air, (2) so that different solutions may be studied under similar conditions which may be easily and accurately reproduced, and (3) so that they may be conveniently filled with solution and drained and cleaned after a series of measurements.

The Pyrex-glass cell, $A B$, of about $140-\mathrm{ml}$ capacity, has a compartment, $A$, for the silver-silver chloride electrodes and a compartment, $B$, for the hydrogen electrodes. The electrodes are supported in rubber stoppers inserted in the openings of the compartments. In all measurements two pairs of electrodes are employed in the solution. Electrodes which do not agree better than $0.05 \mathrm{mv}$ are not considered to be functioning properly. The hydrogen inlet tube of compartment $B$ is $192170-39-2$ 
sealed to the outlet tube of a Pyrex-glass bubble tube, $D$, of about 40-ml capacity, which consists of an outer glass tube and an inner glass rod around which is sealed a glass spiral of six turns. The bubble tube serves to equilibrate the hydrogen gas with water vapor prior to its entrance into the solution in compartment $B$, thus preventing changes in the concentration of the solution and errors in the emf. The efficiency of the bubble tube was tested by filling it with distilled

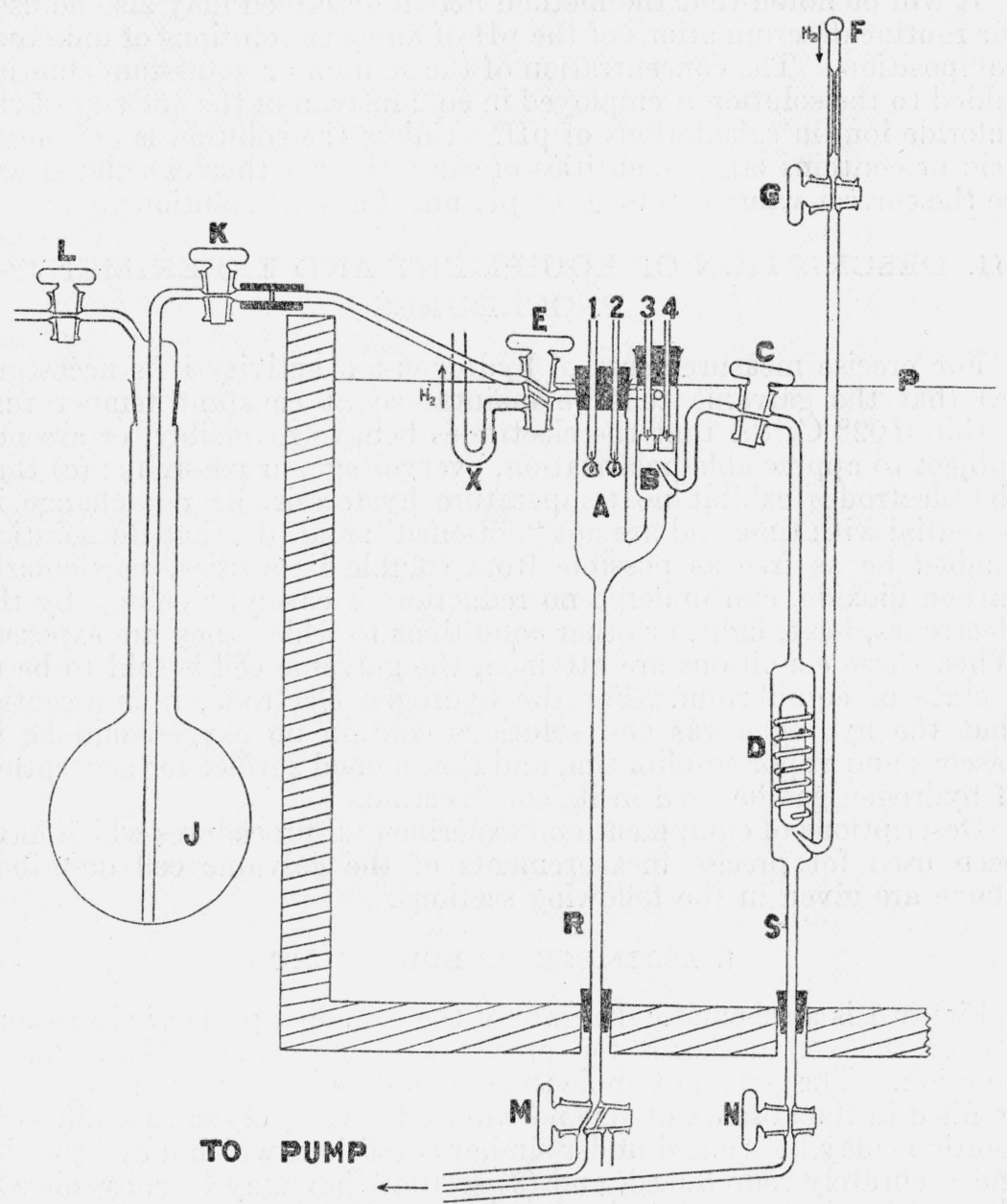

FIgURE 1.-Schematic diagram of principal parts of apparatus employed for accurate measurements of hydrogen-ion activities in solutions.

water and passing hydrogen through it and then through $50 \mathrm{~g}$ of water contained in a weighed Erlenmeyer flask completely immersed in a constant-temperature bath. After 10 hours of flow, no change in the weight of the water in the flask was found. Stopcock $C$ is inserted between the bubble tube and compartment $B$ to aid in filling the cell and bubble tube with solution. The cell and bubble tube are installed in the thermostat, $P$, as indicated schematically in figure 1 , and, in 


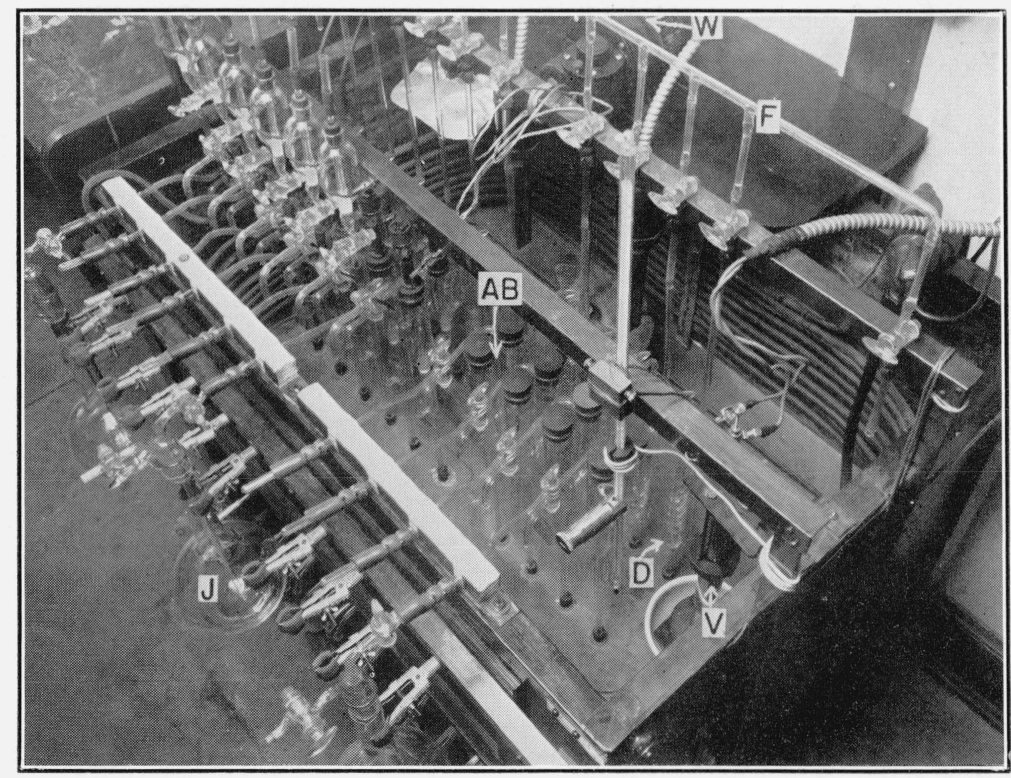

FIgURE 2.-Assembly of 10 cells and 10 hydrogen-gas bubble tubes in a water thermostat and the interior arrangement of the water thermostat. 


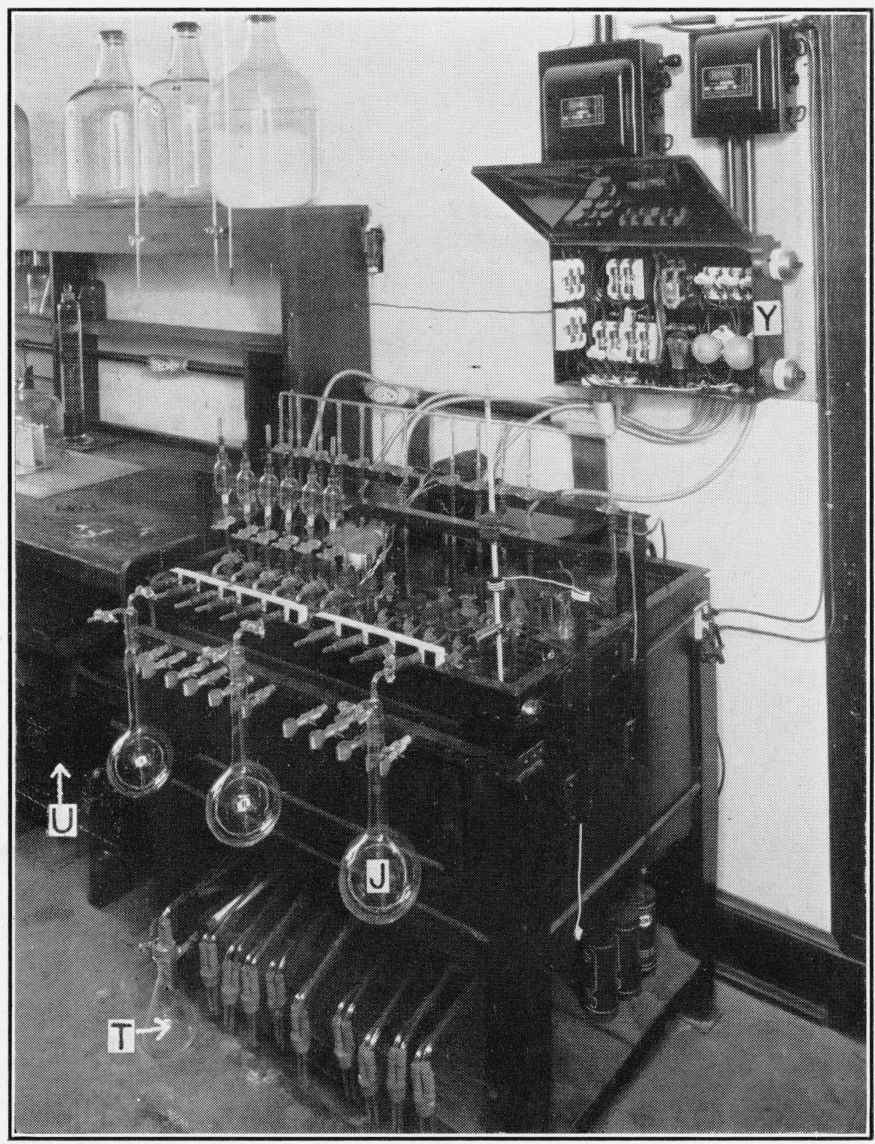

FIGURE 3.-Complete apparatus, including the drainage flasks, vacuum line and pump, shielded emf leads, vacuum-tube-relay box, supports for the solution flasks, and accessories employed in the accurate measurements of hydrogen-ion activities in solutions. 
figure 2, with the drainage tubes, $R$ and $S$, protruding through rubber stoppers inserted into $1 / 2$-in. holes in the bottom of the thermostat. The hydrogen inlet tube is sealed to a glass manifold, $F$, through which the hydrogen gas enters the apparatus. Stopcock $G$ is inserted between the manifold and the bubble tube to aid in regulating the rate of flow of the gas.

The tube leading from the rear of compartment $B$ to flask $J$, containing the solution to be studied, serves two purposes: (1) To convey the solution from flask $J$ to $A, B$, and $D$ when stopcock $E$ is in the position shown, and (2) as the outlet tube for hydrogen gas from $B$ when stopcock $E$ is turned through an angle of $180^{\circ}$. This tube is connected to the delivery tube of flask $J$ by rubber tubing. The hydrogen outlet tube and stopcock $E$ are nearly completely immersed in the bath to prevent water condensing in them and running back into the cell, which would dilute the solution and cause errors in the emf measurements. A rubber tube extending over the edge of the thermostat is connected to the hydrogen outlet tube at position $X$.

The apparatus is a single glass unit from stopcock $G$ to stopcock $K$ and to stopcocks $M$ and $N$, except for the small portion of rubber tubing joining flask $J$ to the apparatus proper. All stopcocks are cleaned and greased before each series of measurements. Stopcock $C$ is in the bath to prevent condensation of water vapor from the hydrogen gas as it passes from the bubble tube to the cell. The tube bearing the stopcock has a $5^{\circ}$ slope toward the bubble tube, so that if any water does leak through the stopcock from the thermostat it will drain into the bubble tube and not the cell.

Ten assemblies ${ }^{7}$ of this type are mounted in the thermostat shown in figure 2. They are supplied simultaneously with hydrogen from a cylinder through the manifold, $F$. The 3 inches of capillary tubing inserted between manifold $F$ and stopcock $G$ aid in equalizing the flow of hydrogen gas in the 10 assemblies. The tubes $R$ and $S$ of each assembly are connected to a drainage flask, $T$, shown in figure 3 . The apparatus and the drainage flask are evacuated by means of a Hyvac pump, $U$, shown at the left in figure 3 , which is protected from water vapor by a glass tower containing calcium chloride and a second tower filled with potassium hydroxide sticks. The pressure is indicated by a mercury manometer inserted between the glass towers and the pump. The apparatus when dry can be evacuated to a pressure of about $0.1 \mathrm{~mm}$ of mercury and has been found to hold this pressure overnight.

\section{PROCEDURE FOR FILLING CELLS AND BUBBLE TUBES}

The apparatus is rinsed and filled with solution in the absence of air as follows. Immediately after the rubber stoppers supporting the electrodes are inserted into compartments $A$ and $B$, the entire apparatus from stopcock $G$ to stopcock $K$ is evacuated through stopcocks $M$ and $N$. The stopcocks are then closed and the apparatus gradually filled with hydrogen by opening stopcock $G$. This procedure of evacuating and filling the apparatus with hydrogen is repeated twice and the apparatus finally evacuated. Stopcock $K$ is then opened slightly and the apparatus filled with solution, hydrogen

\footnotetext{
The six cells shown on the left in figures 2 and 3 are designed for studies of galvanic cells with liquid functions, the details of which will not be considered in this paper.
} 
gas being admitted through stopcock $L$ to flask $J$ to maintain constant pressure within it and to avoid contamination of the solution with air and carbon dioxide. The solution is allowed to remain in the apparatus from 15 to 20 minutes in order to wash it and the electrodes thoroughly. The apparatus is then drained through $M$ and $N$ by evacuation and simultaneously filled with hydrogen, reevacuated, and refilled with solution. This second solution is also kept in the apparatus for 15 to 20 minutes and then withdrawn as above. Finally, the apparatus is evacuated for a third time and completely filled with solution. For efficient flow of the hydrogen, part of the solution in the bubble tube is forced out through stopcock $N$ by means of hydrogen. Since the hydrogen electrode functions best when only partially immersed in solution and the gas must escape through stopcock $E$, part of the solution in compartment $B$ is likewise forced out through stopcock $M$ by hydrogen. The flow of hydrogen is then regulated at a rate of about two bubbles per second. The gas passes around the spiral in the bubble tube and over the hydrogen electrodes in compartment $B$ and escapes through stopcock $E$ and tube $X$.

\section{PREPARATION OF SOLUTIONS}

Conductivity water employed for the preparation of all solutions is obtained by oxidation of the organic matter in distilled water with alkaline permanganate, distillation in an all-glass still, and subsequent redistillation in a tin still [13]. The specific conductance of the water in the present work was $1.0 \times 10^{-6}$ mho. Dissolved air and carbon dioxide are then removed by boiling the water under reduced pressure for 3 to 4 hours and by cooling it in a steady stream of hydrogen gas. This water is then stored under an atmosphere of hydrogen. The dissolved gases in the solutions studied are also removed by boiling them under reduced pressure and then cooling them in a stream of hydrogen gas. For those solutions which decompose when heated, even under reduced pressure, the dissolved gases are removed by bubbling hydrogen through the solution at room temperature for 2 to 3 hours. In all cases, corrections for loss of water from the solutions by evaporation during these operations are made by determining the weight of the solutions before and after deaeration. Purified salts are always used in preparations of the solutions. Weighings are made in a constant temperature room $\left(25^{\circ} \pm 0.2^{\circ} \mathrm{C}\right)$ of about 50-percent relative humidity. All weights are corrected to the "vacuum" basis. The weights used were calibrated by the Mass Section of the Bureau.

\section{HYDROGEN ELECTRODES AND PURIFICATION OF HYDROGEN GAS}

The bases of the hydrogen electrodes are constructed of platinum foil ( 10 by 15 by $0.2 \mathrm{~mm}$ ) welded to a platinum wire sealed in the end of a glass tube. The foil is cleaned for about 3 minutes in aqua regia diluted with an equal volume of water and washed in distilled water. A chloroplatinic acid solution is prepared by dissolving $3 \mathrm{~g}$ of platinum in aqua regia, evaporating it to dryness on a water bath, moistening the residue with concentrated hydrochloric acid, reevaporating and dissolving the residue in $100 \mathrm{ml}$ of $0.25 \mathrm{~N}$ hydrochloric acid. One milliliter of 5-percent lead acetate solution is added. 
The solution must be perfectly clear. The foil is then plated with a thin coat of platinum black by electrolysis in the chloroplatinic acid solution for three minutes at a current density of 250 ma per $\mathrm{cm}^{2}$ of electrode surface. After the electrodes are coated with platinum black they are thoroughly washed and stored in distilled water. Newly plated electrodes are always used for each experiment. They are not previously saturated with hydrogen gas by electrolysis in sulfuric acid, as is often done in practice, since in the procedure described above, they are dried by evacuation, thus making any presaturation valueless. Furthermore, Loomis and Acree [14] found that it was unnecessary to saturate a hydrogen electrode in this way. Possible changes in the $\mathrm{pH}$ of dilute solutions by contamination with $\mathrm{H}_{2} \mathrm{SO}_{4}$ from the sponge are also avoided. Electrodes prepared in this manner have been found to be reproducible and to function reversibly within $0.02 \mathrm{mv}$, when used in solutions which are not reduced by the hydrogen electrode. The preparation of electrodes for use in solutions which may be reduced by the hydrogen electrode is not considered in this paper.

Commercial electrolytic hydrogen gas stored in cylinders is used for the hydrogen electrodes and deaeration of the solutions. It is important that the last traces of oxygen be removed from the hydrogen gas. MacInnes and Cowperthwaite [15] observed differences as large as $50 \mathrm{mv}$ between the potentials of two hydrogen electrodes when commercial hydrogen gas is used without purification. Lorch [16] showed that 0.92 percent of oxygen in hydrogen gas will cause a chemical polarization of the hydrogen electrode displacing the potential $0.78 \mathrm{mv}$ from the equilibrium value. The hydrogen gas is therefore purified by passing it through a soda-lime scrubber to remove carbon dioxide, through a Chamberland filter to remove soda-lime dust, and finally over palladinized asbestos contained in a Pyrexglass tube, $30 \mathrm{~cm}$ in length and $1 \mathrm{~cm}$ in diameter, heated to $220^{\circ} \mathrm{C}$ to remove oxygen, as recommended by Loomis and Acree [14]. It is conducted to manifold $F$ (fig. 1 ) through a copper tube of 0.5 -mm bore. The tube is joined to the manifold with de Khotinsky cement.

\section{SILVER-SILVER CHLORIDE ELECTRODES}

Several types of silver-silver chloride electrodes are in common use. They are the electrolytic, thermal-electrolytic, and thermal types. Smith and Taylor have recently shown that if sufficient time is allowed, all three types will give the same potential within $0.02 \mathrm{mv}$ with respect to the same solution containing chloride ion and that the thermal-electrolytic type attains a state of equilibrium sooner than the other two types. Since the thermal-electrolytic type may be more easily prepared in a state of high purity than the other two, ${ }^{8}$ and because its potential relative to the "normal hydrogen electrode" is accurately known, it was used in this work. It is considered the best type for use in precise measurements.

The method of preparation proposed by Harned [18] was followed with slight modifications. The base of the silver-silver chloride electrode consists of a helix ( 4 turns) of platinum wire of about $0.3-\mathrm{mm}$

\footnotetext{
${ }^{8}$ In the preparation of the electrolytic type, the silver is deposited by electrolysis from a solution of potas${ }^{8}$ In the preparation of the electrolytic type, the silver is deposited by electrolysis from 8 solution of potas-
sium silver cyanide and complete removal of the cyanide is bothersome. In the thermal type, silver-oxide and silver-chlorate pastes are heated in an oven at $700^{\circ} \mathrm{C}$, and care must be taken to svoid explosions. Furthermore, it is difficult to sscertain if all the silver chlorate has been reduced to silver chloride.
} 
diameter. A glass tube sealed to the helix serves as the electrode support. Silver-oxide paste is prepared from hot solutions of silver nitrate and sodium hydroxide, thoroughly washed in distilled water, inserted in the helix, and is then converted to metallic silver by heating to $450^{\circ} \mathrm{C}$ in an electric furnace. The helix with the metallic silver is then cooled, and the silver partially converted to silver chloride by electrolysis in a normal solution of purified hydrochloric acid for 2 hours at a current density of $8 \mathrm{ma}$ per $\mathrm{cm}^{2}$ of electrode surface.

Güntelberg [19] observed that traces of bromide ion produce appreciable changes in the potential of silver-silver chloride electrodes. For example, he found that the equilibrium potential for the silversilver chloride electrode in a solution of $0.0968 \mathrm{M} \mathrm{KCl}, 0.001 \mathrm{M}$ $\mathrm{PbCl}_{2}$ and $0.002 \mathrm{M} \mathrm{HCl}$ was lowered $0.53 \mathrm{mv}$ and $2.68 \mathrm{mv}$ by the addition, respectively, of 0.01 mole percent and 0.05 mole percent of $\mathrm{KBr}$. The hydrochloric acid used in the preparation of the silversilver chloride electrodes was prepared by the method of Brunel and Acree [20], which should give a solution of hydrochloric acid containing no bromide ion. Hydrogen chloride gas, generated in a Kipp generator by the action of concentrated sulfuric acid on pure fused ammonium chloride, is passed into conductivity water. After leaving the generator, the gas is passed at a rate of two bubbles per second through a wash bottle containing concentrated sulfuric acid. The hydrochloric acid was tested for sulfate ion and the test was negative.

The electrodes are about $7 \mathrm{~mm}$ in diameter. They are thoroughly washed and soaked overnight in distilled water, before being used in experiments. Smith and Taylor find that electrodes should be aged in the solution to be studied to prevent concentration polarization (due to differences between the concentration in the pores of the electrode and the bulk solution) which may produce errors of the order of $0.1 \mathrm{mv}$ in the emf if the electrodes are used prior to 10 hours of aging. It will be evident from the data given in table 1 that soaking the electrodes overnight in distilled water and the procedure of evacuation described above greatly reduce, if they do not entirely eliminate the concentration difference which gives rise to polarization.

\section{THERMOSTAT AND TEMPERATURE REGULATION}

The thermostat shown in figures 2 and 3 consists, in part, of a thermally insulated copper tank, 16 by 36 by 24 inches, filled with water. It is supported 16 inches above the floor, as shown in figure 3. The temperature of the water is controlled by means of a mercury regulator, $V$, (fig. 2), sensitive to $0.001^{\circ} \mathrm{C}$. It is included in an electric circuit with a vacuum tube, a light-duty relay, and a heavy-duty relay, housed in a metal box, $Y$ (fig. 3), and a 1,500-watt immersion heater on the bottom of the bath. The mercury regulator was designed so that it can be adjusted quickly for use at temperatures from $0^{\circ}$ to $60^{\circ} \mathrm{C}$, or higher. A cross section is shown in figure 4 . While the temperature of the bath is being raised or lowered, the ground-glass stopper, $A$, is lifted from its seat, so that the mercury remains at approximately the same level in bulb, $B$, and capillary tube, $C$. The stopper is seated when the desired temperature is reached and is held in place by rubber bands. The fixed terminal, $D$, and the adjustable terminal, $E$, are both of platinum wire. A glass 
bead, $F$, is sealed on the platinum wire used in the capillary tube to keep the wire in position.

The temperature of the bath is measured by means of a thermometer, graduated in tenths of a degree from $-10^{\circ}$ to $102^{\circ} \mathrm{C}$, calibrated by the Thermometry Section of the National Bureau of Standards. The ice point is redetermined at frequent intervals. The temperature of the bath was constant to about $0.01^{\circ} \mathrm{C}$ at all the temperatures employed. For temperatures below that of the room, the bath is cooled by means of a $1 / 2-h$ p refrigerator unit with 10 coils of $1 / 2$-inch copper tubing serving as the expansion coil placed at the inside wall of the bath (fig. 2). To control the temperature of the bath at or below room temperature, the refrigerator is operated continuously and heat supplied by electric immersion heaters and the temperature regulated in the same manner as for higher temperatures. The water of the bath is stirred by means of a 10-inch, 6-blade propeller, making 108 rpm, driven by a motor, $W$, (fig. 2 ), with built-in reduction gear. The effectiveness of the stirring was tested by exploring the bath at $0^{\circ}$ and $25^{\circ} \mathrm{C}$ with a Beckmano thermometer. The temperature was found to be uniform within $\pm 0.002^{\circ} \mathrm{C}$. Two auxiliary 1,000 -watt immersion hea ters are employed independently of the vacuum tube-relay circuit so that rapid changes in the temperature of the bath may be made when desired. Other features of the thermostat and assembly, such as the manner in which the solution flasks are held in position and the support for the tubes leading from the flasks to the cells, are shown in figures 2 and 3.

\section{INSTRUMENTS FOR MEASURING ELECTROMOTIVE FORCE}

The measurements of the emf of the galvanic cells are made with a Leeds \& Northrup type $K$ potentiometer, cali-

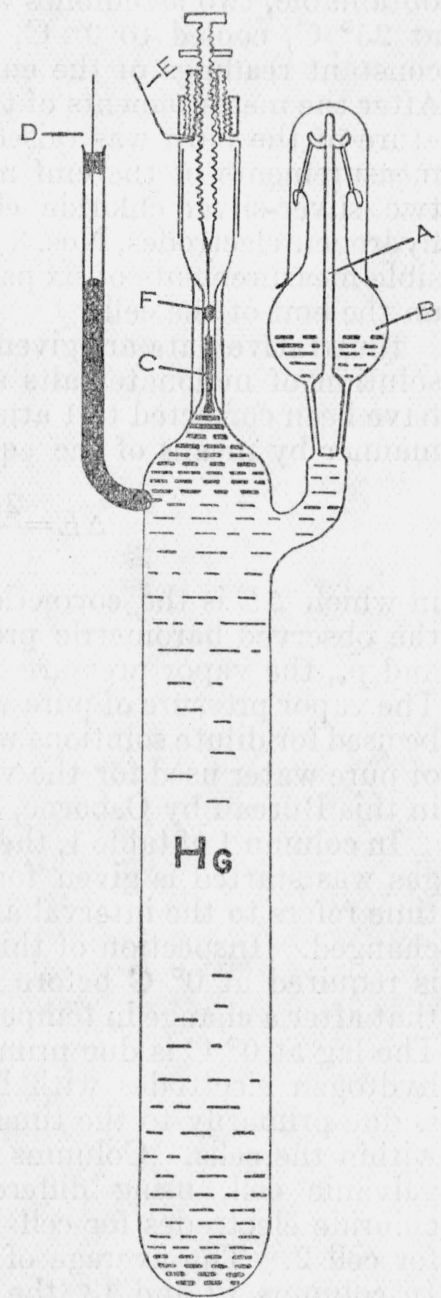

Figure 4.-Cross section of the mercury regulator for control of temperatures of a water bath from $0^{\circ}$ to $60^{\circ} \mathrm{C}$, or higher.

brated by the Resistance Measurements Section of the Bureau, with a Leeds \& Northrup type $R$ galvanometer and an unsaturated Weston cell. Contact between the potentiometer leads and all electrodes is made with mercury contained in the electrode supports. 


\section{DATA ILLUSTRATING PRECISION OF MEASUREMENTS}

To illustrate the reproducibility of the results and the precision obtainable, two assemblies were filled with the same solution (table 1) at $25^{\circ} \mathrm{C}$, cooled to $0^{\circ} \mathrm{C}$, and the emf recorded at intervals until constant readings of the emf or equilibria of the cells were attained. After the measurements of the emf at $0^{\circ} \mathrm{C}$ were recorded, the temperature of the bath was raised from $0^{\circ}$ to $60^{\circ} \mathrm{C}$ in 5-degree steps and measurements of the emf made at each temperature. In each cell, two silver-silver chloride electrodes, Nos. 1 and 2 (fig. 1) and two hydrogen electrodes, Nos. 3 and 4, were employed, thus making possible measurements of six pairs of electrodes and a total of four checks on the emf of the cell.

Illustrative data are given in table 1 for a galvanic cell containing a solution of malonate salts and sodium chloride. ${ }^{9}$ These emf values have been corrected to 1 atmosphere of hydrogen pressure in the usual manner by means of the equation [21]

$$
\Delta E=\frac{2.3026 R T}{2 F} \log \frac{760}{\left(p_{b}-p_{v}\right)},
$$

in which $\Delta E$ is the correction to be applied to the measured emf; $p_{b}$, the observed barometric pressure in millimeters of mercury at $0^{\circ} \mathrm{C}$; and $p_{v}$, the vapor pressure of the solution in millimeters of mercury. The vapor pressure of pure water was used for $p_{v}$ in this work and may be used for dilute solutions with negligible error. The vapor pressures of pure water used for the various temperatures were those obtained in this Bureau by Osborne, Stimson, and Ginnings [22].

In column 1 of table 1 , the time in minutes after the flow of hydrogen gas was started is given for $0^{\circ} \mathrm{C}$. For the other temperatures, the time refers to the interval after the temperature of the bath had been changed. Inspection of this table shows that approximately 4 hours is required at $0^{\circ} \mathrm{C}$ before equilibrium of the cells is attained and that after a change in temperature only half an hour or less is required. The lag at $0^{\circ} \mathrm{C}$ is due primarily to the time required to saturate the hydrogen electrodes with hydrogen. At the other temperatures it is due primarily to the time required to obtain constant temperature within the cells. Columns 3 and 4 give the values of the emf of the galvanic cell, using different pairs of hydrogen and silver-silver chloride electrodes for cell 1 ; and columns 7 and 8 give similar data for cell 2. The average of the four readings is given in column 11 . In columns 12 and 13 , the maximum and average deviations of the individual emf from the average, respectively, are given. The maximum deviation ranges from 0.02 to $0.04 \mathrm{mv}$ for different cells, which is equivalent, respectively to 0.0004 and to $0.0007 \mathrm{pH}$ unit at $25^{\circ} \mathrm{C}$. The average deviation is between 0.01 and $0.02 \mathrm{mv}$, equivalent, respectively, to 0.0002 and $0.0004 \mathrm{pH}$ unit at $25^{\circ} \mathrm{C}$. Further inspection of the data of this table shows that the emf obtained for cell 1 is in close agreement with the emf obtained for cell 2 , thus affording a good check upon the reproducibility of the results obtained with the method employed in filling the cells and in preparing the electrodes.

\footnotetext{
Acknowledgment is made to John O. Burton, formerly of this "Bureau"and now Chief Research Engineer of the Minnesota and Ontario Paper Co., International Falls, Minn., for the purification of the malonic acid, hydrochloric acid, and sodium hydroxide used in the preparation of these solutions and for aid in obtaining some of the data.
} 
After the final measurements of the emf were made at $60^{\circ} \mathrm{C}$, the temperature of the bath was lowered to $45^{\circ} \mathrm{C}$ in order to learn whether the emf of the cells would agree with the first values obtained at $45^{\circ} \mathrm{C}$ and to determine if there was a temperature hysteresis. The value of $652.87 \mathrm{mv}$ agrees closely with the $652.84 \mathrm{mv}$ value previously obtained. The bath was then cooled to $25^{\circ} \mathrm{C}$ to obtain a further check. The value of $635.44 \mathrm{mv}$ agrees closely with the $635.40 \mathrm{mv}$ value previously obtained at $25^{\circ} \mathrm{C}$. Data obtained at duplicate temperatures generally agree to within $0.04 \mathrm{mv}$, showing that proper equilibria can be obtained at all the temperatures; and that the electrodes function properly and exhibit no temperature hysteresis or aging effects. Inspection of the data of table 1 shows that a change of $0.01^{\circ} \mathrm{C}$ produces a change of about $0.009 \mathrm{mv}$ in the emf, which is slightly less than the experimental error of the electrical measurements.

In columns 5 and 9 the differences observed in the potential between the two silver-silver chloride electrodes are given. It will be seen that this difference is only 0.01 to $0.03 \mathrm{mv}$ at equilibrium. Similar observations with hydrogen electrodes are given in columns 6 and 10 . These data also show that the electrodes exhibit no appreciable temperature hysteresis. Furthermore, no aging effects were observed over a period of 15 hours, which is the time that elapsed between the first and second set of readings at $25^{\circ} \mathrm{C}$. The differences between duplicate electrodes account almost entirely for the deviations found for the emf of the galvanic cells, indicating that the method of filling the cells and making the measurements is better than stated above and that the limiting factor is the reproducibility of the electrodes. Similar precision was obtained for other galvanic cells containing aqueous solutions of various concentrations of malonate salts [23] and solutions prepared from other organic aliphatic materials.

Only estimates can be made of the accuracy obtainable by the method and procedures described in this paper. The uncertainty in $E^{\circ}$ is estimated as $0.05 \mathrm{mv}$ from a consideration of the work of Harned and Ehlers [9]. On the basis of an uncertainty of 0.1 percent in the dielectric constant of water ${ }^{10}$ and the uncertainties in $R, T_{0}, F, \epsilon$, and $k$ given by Wensel [24], the uncertainties in 2.3026RT/F, $A$, and $B$ are respectively, $0.02 \mathrm{mv}, 0.003$, and 0.001 reciprocal angstrom. The uncertainty in the concentration is taken as 0.1 percent, even though, in many cases, it may be only 0.01 percent. An error of $0.05 \mathrm{mv}$ in $E^{\circ}$ and an error of $0.02 \mathrm{mv}$ in $2.3026 R T / F$ are equivalent, respectively, to errors of 0.0008 and $0.0006 \mathrm{pH}$ unit. An error of 0.003 in $A$ at $25^{\circ} \mathrm{C}$, combined with an error of 0.001 reciprocal angstrom in $B$, produces an error of $0.0012 \mathrm{pH}$ unit at a concentration of 1 molar and an error of about $0.0003 \mathrm{pH}$ unit at 0.01 molar-a value of 3 angstroms was used for $a_{i}$ in these calculations. Finally, an error of 0.1 percent in the concentration at 1 molar results in an error of only $0.0005 \mathrm{pH}$ unit. The experimental error in $E$ is less than half the uncertainty which has been assigned to $E^{\circ}$, while the error in $t$ is of the same order as the uncertainty in $T_{0}$.

10 The gezeral constants $A$ and $B$ used in eq 4 are defined by

and

$$
A=\frac{\sqrt{2 \pi}}{2.3026}\left(\frac{\epsilon}{\sqrt{D k\left(t+T_{0}\right)}}\right)^{3}\left(\frac{N}{1000}\right) 1 / 2
$$

$$
B=\frac{4.6052 D k\left(t+T_{0}^{*}\right)}{\epsilon^{2}} A,
$$

where $\epsilon$ is the electronic charge, $N$ the Avogadro number, $D$ the dielectric constant of water, $k$ the Boltzmann constant, $t$ the centigrade temperature, and $T_{0}$ the Kelvin temperature of the ice point. 
TABLE 1. - Data for the galvanic cell $\mathrm{Pt}\left|\mathrm{H}_{2}(\mathrm{~g})\right|$ sodium malonate $(0.029535 \mathrm{M})$, sodium acid malonate $(0.029585 \mathrm{M})$, sodium chloride (0.029585 M) $|\mathrm{AgCl}(\mathrm{s})| \mathrm{Ag}(\mathrm{s})$ illustrating the precision obtainable from $0^{\circ}$ to $60^{\circ} \mathrm{C}$ with galvanic cells without liquid junction

\begin{tabular}{|c|c|c|c|c|c|c|c|c|c|c|c|c|c|c|}
\hline \multirow{2}{*}{$\begin{array}{l}\text { Time after starting the hydro- } \\
\text { gen flow or after a change in } \\
\text { temperature }\end{array}$} & \multirow{2}{*}{$\begin{array}{l}\text { Tem- } \\
\text { pera- } \\
\text { ture }\end{array}$} & \multicolumn{4}{|c|}{$\begin{array}{l}\text { Data for cell } 1 \text { containing the malonate } \\
\text { solution and using electrode combina- } \\
\text { tions- }\end{array}$} & \multicolumn{4}{|c|}{$\begin{array}{l}\text { Data for cell } 2 \text { containing the malonate } \\
\text { solution and using electrode combina- } \\
\text { tions- }\end{array}$} & \multirow{2}{*}{$\begin{array}{c}\text { A verage } \\
\text { emf }\end{array}$} & \multirow{2}{*}{$\begin{array}{l}\text { Maxi- } \\
\text { mum? } \\
\text { deviation } \\
\text { from the } \\
\text { average } \\
\text { emf }\end{array}$} & \multirow{2}{*}{$\begin{array}{l}\text { A verage 2 } \\
\text { deviation } \\
\text { from the } \\
\text { average } \\
\text { emf }\end{array}$} & \multirow{2}{*}{$\begin{array}{l}\text { Average } \\
\text { pH } \\
\text { values : }\end{array}$} & \multirow{2}{*}{$\begin{array}{l}\text { Average } \\
\text { pH } \\
\text { values }\end{array}$} \\
\hline & & $1-3$ & $2-4$ & $1-2^{1}$ & $3-41$ & $1-3$ & $2-4$ & $1-21$ & $3-41$ & & & & & \\
\hline 1 & 2 & 3 & 4 & 5 & 6 & 7 & 8 & 9 & 10 & 11 & 12 & 13 & 14 & 15 \\
\hline $\begin{array}{l}\text { Minutes } \\
60 \\
90 \\
120 \\
150 \\
180 \\
210 \\
240 \\
300 \\
330 \\
360 \\
\text { Equilibrium value }\end{array}$ & $\begin{array}{l}{ }^{\circ} \mathrm{C} \\
0 \\
0 \\
0 \\
0 \\
0 \\
0 \\
0 \\
0 \\
0 \\
0 \\
0\end{array}$ & $\begin{array}{l}m v \\
613.33 \\
613.49 \\
613.61 \\
613.71 \\
613.78 \\
613.85 \\
613.89 \\
613.93 \\
613.93 \\
613.93 \\
613.93 \\
613.93\end{array}$ & $\begin{array}{l}m \text { } \\
613.26 \\
613.44 \\
613.58 \\
613.69 \\
613.79 \\
613.88 \\
813.94 \\
613.95 \\
613.96 \\
613.95 \\
613.95 \\
613.95\end{array}$ & $\begin{array}{l}m v \\
+0.04 \\
+.06 \\
+.03 \\
.00 \\
-.02 \\
-.02 \\
=.03 \\
=.01 \\
=.01 \\
-.01 \\
-.01 \\
-0.01\end{array}$ & $\begin{array}{l}m o \\
-0.03 \\
+.01 \\
.00 \\
-.02 \\
-.01 \\
+.01 \\
+.02 \\
+.01 \\
+.02 \\
+.01 \\
+.01 \\
+0.01\end{array}$ & $\begin{array}{l}m v \\
613.24 \\
613.44 \\
613.57 \\
613.89 \\
613.74 \\
613.82 \\
613.88 \\
613.97 \\
613.89 \\
613.90 \\
613.90 \\
613.90\end{array}$ & $\begin{array}{l}m v \\
613.23 \\
613.41 \\
613.59 \\
613.68 \\
613.77 \\
613.85 \\
613.93 \\
613.93 \\
613.93 \\
613.93 \\
613.93 \\
613.93\end{array}$ & $\begin{array}{l}m v \\
+0.04 \\
+.04 \\
+.04 \\
+.04 \\
-.03 \\
-.04 \\
-.03 \\
-.03 \\
-.02 \\
-.02 \\
-.02 \\
-0.02\end{array}$ & $\begin{array}{l}m v \\
+0.03 \\
+.01 \\
+.02 \\
+.03 \\
.00 \\
-.01 \\
+.02 \\
+.03 \\
+.02 \\
+.01 \\
+.01 \\
+0.01\end{array}$ & 613.93 & 0.03 & 0.01 & 5.323 & $\begin{array}{c}\ldots . . \\
\\
\end{array}$ \\
\hline $\begin{array}{l}10 \\
60 \\
60 \\
\text { Fquilibrium value }\end{array}$ & $\begin{array}{l}20 \\
20 \\
20 \\
20\end{array}$ & $\begin{array}{l}630.87 \\
630.97 \\
631.01 \\
631.01 \\
631.01\end{array}$ & $\begin{array}{l}630.93 \\
631.03 \\
331.03 \\
631.03 \\
631.03\end{array}$ & $\begin{array}{l}-.04 \\
-.03 \\
-.01 \\
-.01 \\
-0.01\end{array}$ & $\begin{array}{r}+.02 \\
+.02 \\
+.01 \\
+.01 \\
+0.01\end{array}$ & $\begin{array}{l}630.91 \\
630.96 \\
630.99 \\
630.99 \\
630.99\end{array}$ & $\begin{array}{l}630.96 \\
631.00 \\
631.00 \\
631.00 \\
631.00\end{array}$ & $\begin{array}{r}-.02 \\
-.02 \\
.00 \\
.00 \\
0.00\end{array}$ & $\begin{array}{r}+.03 \\
+.02 \\
+.01 \\
+.01 \\
+0.01\end{array}$ & 613.01 & 0.02 & 0.01 & 5.323 & \begin{tabular}{l}
-1.2. \\
\hdashline 5.250
\end{tabular} \\
\hline $\begin{array}{l}10 \\
60 \\
60 \\
\text { Equilibrium value }\end{array}$ & $\begin{array}{l}25 \\
25 \\
25 \\
25 \\
25\end{array}$ & $\begin{array}{l}635.21 \\
635.29 \\
635.39 \\
635.39 \\
635.39 \\
635.39\end{array}$ & $\begin{array}{l}635.27 \\
635.33 \\
635.43 \\
635.42 \\
635.42 \\
635.42\end{array}$ & $\begin{array}{l}-.04 \\
-.01 \\
-.03 \\
-.02 \\
-.02 \\
-0.02\end{array}$ & $\begin{array}{r}+.02 \\
+.02 \\
+.01 \\
+.01 \\
+.01 \\
+0.01\end{array}$ & $\begin{array}{l}635.27 \\
635.41 \\
635.39 \\
635.39 \\
635.39 \\
635.39\end{array}$ & $\begin{array}{l}635.31 \\
635.42 \\
635.41 \\
635.41 \\
635.41 \\
635.41\end{array}$ & $\begin{array}{l}=.05 \\
=.01 \\
=.01 \\
=.01 \\
=.01 \\
=0.01\end{array}$ & $\begin{array}{r}-.01 \\
+.00 \\
+.01 \\
+.01 \\
+.01 \\
+0.01\end{array}$ & 635.40 & 0.02 & $0.01^{-}$ & 5.331 & \begin{tabular}{ll}
-1.1. \\
\hdashline 5.258
\end{tabular} \\
\hline 60 & $\begin{array}{l}45 \\
45 \\
45 \\
45\end{array}$ & $\begin{array}{l}652.71 \\
652.85 \\
652.85 \\
652.85 \\
652.85\end{array}$ & $\begin{array}{l}652.77 \\
652.86 \\
652.86 \\
652.86 \\
652.86\end{array}$ & $\begin{array}{r}-.04 \\
+.00 \\
.01 \\
.00 \\
0.00\end{array}$ & $\begin{array}{r}+.02 \\
+.01 \\
+.02 \\
+.01 \\
+0.01\end{array}$ & $\begin{array}{l}652.68 \\
652.79 \\
652.80 \\
652.80 \\
652.80\end{array}$ & $\begin{array}{l}652.73 \\
652.82 \\
652.82 \\
6 \overline{2} .82 \\
652.82\end{array}$ & $\begin{array}{l}-.02 \\
=.02 \\
=.01 \\
-.01 \\
-0.01\end{array}$ & $\begin{array}{r}+.03 \\
+.01 \\
+.01 \\
+.01 \\
+0.01\end{array}$ & 652.84 & 0.04 & 0.02 & 5.384 & 5. 312 \\
\hline $\begin{array}{l}10 \\
45 \\
60 \\
75 \\
\text { Equilibrium value }\end{array}$ & $\begin{array}{l}60 \\
60 \\
60 \\
60 \\
60\end{array}$ & $\begin{array}{l}666.14 \\
666.21 \\
666.25 \\
666.25 \\
666.25 \\
666.25\end{array}$ & $\begin{array}{l}666.17 \\
666.23 \\
666.21 \\
666.21 \\
666.21 \\
666.21\end{array}$ & $\begin{array}{r}-.02 \\
+.00 \\
+.03 \\
+.03 \\
+.03 \\
+0.03\end{array}$ & $\begin{array}{l}+.01 \\
+.02 \\
-.01 \\
-.01 \\
-.01 \\
-0.01\end{array}$ & $\begin{array}{l}666.16 \\
666.20 \\
666.22 \\
666.22 \\
666.22 \\
866.22\end{array}$ & $\begin{array}{l}660.19 \\
666.23 \\
686.26 \\
666.27 \\
636.27 \\
666.27\end{array}$ & $\begin{array}{r}-.04 \\
=.02 \\
-.06 \\
=.03 \\
-.03 \\
-0.03\end{array}$ & $\begin{array}{r}-.01 \\
+.01 \\
-.02 \\
+.02 \\
+.02 \\
+0.02\end{array}$ & 666.24 & $\begin{array}{c}0.03 \\
0.0\end{array}$ & 0.02 & 5.440 & $\begin{array}{c}0.1 \\
5.372\end{array}$ \\
\hline
\end{tabular}




\begin{tabular}{|c|c|c|c|c|c|c|c|c|c|c|c|c|c|c|}
\hline $\begin{array}{l}10 \\
30 \\
60 \\
90 \\
\text { Equilibrium value }\end{array}$ & $\begin{array}{l}45 \\
45 \\
45 \\
45 \\
45\end{array}$ & $\begin{array}{l}653.07 \\
652.91 \\
652.87 \\
652.87 \\
652.87 \\
652.87\end{array}$ & $\begin{array}{l}853.05 \\
652.90 \\
652.86 \\
652.86 \\
652.86 \\
652.86\end{array}$ & $\begin{array}{r}+.03 \\
+.01 \\
+.01 \\
+.01 \\
+.01 \\
+0.01\end{array}$ & $\begin{array}{r}+.01 \\
.00 \\
.00 \\
.00 \\
.00 \\
0.00\end{array}$ & $\begin{array}{l}653.14 \\
652.99 \\
652.89 \\
652.85 \\
652.85 \\
652.85\end{array}$ & $\begin{array}{l}653.15 \\
653.03 \\
652.91 \\
652.89 \\
652.89 \\
652.89\end{array}$ & $\begin{array}{l}-.03 \\
=.05 \\
=.01 \\
=.02 \\
-.02 \\
-0.02\end{array}$ & $\begin{array}{r}-.02 \\
-.01 \\
+.01 \\
+.02 \\
+.02 \\
+0.02\end{array}$ & 652.87 & 0.02 & 0.01 & 5. 384 & 5.312 \\
\hline $\begin{array}{l}30 \\
60 \\
60 \\
\text { Equilibrium value }\end{array}$ & $\begin{array}{l}25 \\
25 \\
25 \\
25 \\
25\end{array}$ & $\begin{array}{l}635.47 \\
635.44 \\
635.42 \\
635.42 \\
635.42 \\
635.42\end{array}$ & $\begin{array}{l}635.56 \\
635.48 \\
635.46 \\
635.46 \\
635.46 \\
635.46\end{array}$ & $\begin{array}{l}-.04 \\
-.02 \\
-.02 \\
-.02 \\
-.02 \\
-0.02\end{array}$ & $\begin{array}{l}+.05 \\
+.02 \\
+.02 \\
+.02 \\
+.02 \\
+0.02\end{array}$ & $\begin{array}{l}635.74 \\
635.53 \\
635.44 \\
635.43 \\
635.43 \\
635.43\end{array}$ & $\begin{array}{l}635.69 \\
635.57 \\
635.48 \\
635.45 \\
635.45 \\
635.45\end{array}$ & $\begin{array}{l}+.03 \\
-.04 \\
=.02 \\
=.01 \\
-.01 \\
-0.01\end{array}$ & $\begin{array}{r}-.02 \\
.00 \\
+.01 \\
+.01 \\
+.01 \\
+0.01\end{array}$ & 635.44 & 0.02 & 0.02 & 5.332 & 5. 259 \\
\hline
\end{tabular}

1 A plus sign indicates that the electrode named first in the heading is the anode.

1 The maximum deviations from the average emf obtained at $5,10,15,30,35,40,50$, and $55^{\circ} \mathrm{O}$ were, respectively, $0.03,0.03,0.02,0.02,0.02,0.03,0.02$, and 0.03 mv, and the average deviations were, respectively, $0.02,0.02,0.01,0.01,0.01,0.02,0.02$, and $0.02 \mathrm{mv}$,

${ }^{8}$ Values obtained by using the numerical values of $a_{i}$ and $\beta$ given on page 662 of this paper.

- Values obtained by assuming the numerical values of $a_{1}$ and $\beta$ in eq 4 are zero. 
It is not possible to give values of the hydrogen-ion activity of the solution here employed until values of $a_{i}$ and $\beta$ are known for $\mathrm{HCl}$ solutions containing malonate salts. However, it has been found ${ }^{11}$ that $\beta$ has a value of zero for this solution, and that $a_{i}$ has a value of $4.99,4.82,4.75,4.29$, and $3.76 \mathrm{~A}$ for the temperatures of $0^{\circ}, 20^{\circ}, 25^{\circ}$, $45^{\circ}$, and $60^{\circ} \mathrm{C}$, respectively. In column 14 of table 1 , the $\mathrm{pH}$ values obtained by using these constants and the values of $R, T_{0}$ and $F$ reported by Wensel [24] are given. In column 15, the $\mathrm{pH}$ values obtained on the assumption that both $a_{i}$ and $\beta$ are zero are listed. It is evident from comparison of these two sets of values, that for this solution, the two sets of $\mathrm{pH}$ values differ by a constant amount of about $0.07 \mathrm{pH}$ unit, which is small for routine measurements. However, for standardization purposes, this difference emphasizes the need for accurate evaluation of the constants $a_{i}$ and $\beta$.

A consideration of the various sources of error and the fact that the uncertainties were assigned magnitudes which the actual errors are not likely to exceed lead to the conclusion that $\mathrm{pH}$ measurements can be made with an accuracy of about $0.001 \mathrm{pH}$ unit.

\section{REFERENCES}

[1] Clark, The Determination of Hydrogen Ions, chap. 23 (Williams \& Wilkin Co., Baltimore, Md., 1928).

[2] Kolthoff and Tekelenburg, Rec. trav. chim. 46, 33 (1927).

[3] Clark and Lubs, J. Biol. Chem. 25, 479 (1916).

[4] MacInnes, Belcher, and Shedlovsky, J. Am. Chem. Soc. 60, 1094 (1938).

[5] Hitcheock and Taylor, J. Am. Chem. Soc. 59, 1812 (1937).

[6] Hitchcock and Taylor, J. Am. Chem. Soc. 60, 2710 (1938).

[7] Hamer, Trans. Electrochem. Soc. "\%, 45 (1937) [a review].

[8] Harned and Ehlers, J. Am. Chem. Soc. 55, 2179 (1933); Harned, J. Franklin Inst. 225, No. 6, 623 (1938) [a review].

[9] Harned and Ehlers, J. Am. Chem. Soc. 54, 1350 (1932).

[10] Int. Critical Tables 6, 321 (1930).

[11] Debye and Hückel, Physik. Z. 24, 185, 305, 334 (1923).

[12] Hückel, Physik. Z. 26, 93 (1925).

[13] Fawcett and Acree, Ind. Eng. Chem., Anal. Ed. 2, 78 (1930).

[14] Loomis and Acree, Am. Chem. J. 46, 585 (1911).

[15] MacInnes and Cowperthwaite, J. Am. Chem. Soc. 53, 555 (1931).

[16] Lorch, Trans. Electrochem. Soc. 55, 2194 (1933).

[17] Smith and Taylor, J. Research NBS 20, 837 (1938) RP1108 [a review].

[18] Harned, J. Am. Chem. Soc. 51, 416 (1929).

[19] Güntelberg, Studier over Elektrolyt-Aktiviteter. I-Vandige Oplösninger, G. E. C. Gads Forlag-Köbenhavn. [Dissertation] (1938).

[20] Brunel and Acree, Am. Chem. J. 36, 117 (1906).

[21] Loomis and Acree, J. Am. Chem. Soc. 38, 2391 (1916); Lewis and Randall, J. Am. Chem. Soc. 36, 1969 (1914); Ellis, J. Am. Chem. Soc. 38, 737 (1916).

[22] Osborne, Stimson, and Ginnings, J. Research NBS 23, 261 (1939) RP1229.

[23] Burton, Univ. Maryland, College Park, Md., [Dissertation] (June 1937.)

[24] Wensel, J. Research NBS 22, 375 (1939) RP1189.

Washington, October 13, 1939.

"Hamer, Burton, and Acree, publication pending. 